\title{
Educational Media Tools and Lifelong Education
}

\author{
Mr.Sce. Dritan Ceka \\ Europian University of Tirana \\ dritanceka@hotmail.com \\ Mr. Anila Jaku \\ University of Shkodra "Luigj Gurakuqi"Albania \\ anila2010@hotmail.co.uk \\ Mr. Sce. Vjosa Imeri \\ Shkolla Fillore, Zenit, Prishtinë \\ vjosaimeri_5@hotmail.com

\section{Mr.Sce. Shkendije Jashari} \\ Shkolla Fillore, Zenit, Prishtinë \\ dija_209@hotmail.com

\section{Mr. Fitore Haliti} \\ Shkolla Fillore, Zenit, Prishtinë \\ fitore.s.haliti@gmail.com
}

\section{Doi:10.5901/jesr.2015.v5n1s1p67}

\section{Abstract}

One of the key factors in lifelong education are also various media including, television, radio, newspapers. The thesis "Educational content in Kosova's television programs" is a thesis that requires multilateral approach as well as psychological, social, pedagogical, andragogical and practical coverage. The importance of this issue remains into the complexity of problem content, because analytic study for the researcher means dividing the problem into two fundamental aspects: the theoretical aspect and practical aspect as well. Actually in Kosova there is a considered number of televisions with 24 hours broadcast, which are identified with a lot of deficiencies, which in fact actualize the problem, but the technological and scientific development especially, have had that impact in human knowledge that the human could not achieve to posses without media help. Latest knowledge become old and are replaced in that speed that it is impossible for human being to cope with these rapid changes if he would not be continuously educated or would not be informed by the media. Besides education, school should prepare the pupil to be able to continue the education further in his life in order to be successful in coping with the latest changes in technology. After finishing the basic education, in order to succeed in his profession and cope with technological, social, economical changes, it requires being continuously educated and informed. Besides everything, the human willingness, involvement and continuous insisting for self improvement help him to achieve success in every field of life, as well as coping with the challenges we face. Without personal involvement for further education even in formal or informal institution, the human as part of society or the society itself could not make it further without media help either television, radio or electronic ones.

Keywords: media, education, culture, television content.

\section{Introduction}

Before 20 or even more years, when man was educated and prepared for a job, with the knowledge that has earned during his schooling, he was able to achieve results at work. Now is a time of rapid and varied changes, because life itself has become more dynamic, and the man will "lose" in these rapid changes, because the school is not able to 
prepare enough the individual for changes brought about time.

School besides providing knowledge must prepare the individual to be able to be educated throughout his life, in order to be more successful in dealing with the changes. After completing basic education, in order to achieve success in the profession and to withstand the economic, social and technical - technological chnages, it is required to be educated in continuously. Man begins his education since childhood and his education is affected by a range of factors and tools. Initially he is prepared in the family, later in different institutions, but also durin working life in various forms. It is considered that aftes the acquisition of a certain fund of knowledge, skilled individual should be educated independently, without the presence of teachers.

Different educational television programs help to broaden and deepen the knowledge of various fields, without having individual contact with anyone, or to follow any sort of continuing education course. Continuous education leaves room to be implied the development of other sectors such as: the economy, education, health and technology, enabling the active involvement of citizens in these developmental processes. This kind of education will enable our inclusion in the family of democratic nations. Without inclusion and adapting to advanced countries, we will find ourselves in a situation of social, educational and technological disadvantaged. Our society will deal with major challenges, so to overcome these challenges, our society should be active society, which educated and moving in step with global developments.

\section{Research Purpose and Objectives}

Television is a very important source of educational advancement of individuals and lifelong education. The role of television has changed the lives and professional development of people. Now television is a medium and a tool which provides good knowledge in many areas. That a man can be educated throughout life, society must ensure that television programs to be diversified, and also the individual is responsible for his education.

The object of study - is to conclude how educational television content affects lifelong education.

\section{Research Questions, Hypothesis and Research Methodology}

Research questions of this research are: Educational TV contents and their importance in lifelong education.

\subsection{Research methodology}

For the realization of this research are used different methods, combined, descriptive. Also, the research was based on quantitative and qualitative methodology, and we also reviewed research, and other documents related to the subject that we have researched.

\subsection{Hypothesis}

Does educational TV content influence lifelong education?

\section{Research Importance}

The problem of educational television content and their relevance to lifelong education, as is extensive and actual, is also very complex. This issue must not be confined within a specific area, inter alia due to the multidimensional character it has. Lifelong Education, in addition to general technological and social progress, represents the television as quite an important factor. Along with global developments, television is becoming a medium and a tool, which will serve us in our continuous efforts to the educational and professional raise

\section{The Purpose of the Research}

The purpose of this research is: analyzing the current situation, time when television broadcast educational programs, and their quality. As a main purpose of this research is to detect and identify other causes and motives, of any nature, which influence educational content on Kosovo's televisions. 


\section{Research Tasks}

From the above statement of the purpose of research derive also the operational tasks. Within the project was envisaged the realization of specific tasks that the nature of the research and work flow enabled to be achieved.

The tasks of the research were to ascertain:

What TV channels offer more educational programs for the citizens of Kosovo;

How much is the television used by the citizens of Kosovo for lifelong education;

How many of those programs help adults to enhance their knowledge.

Which resources are used by the citizens of Kosovo for lifelong education

Which educational programs are the most viewed in our country;

How satisfied are adults with the diversity and quality of the programs they follow;

\section{Lifelong Education}

The aim of the educational policy of any country is to provide opportunities for achieving the appropriate level of education for each one and for all groups of adults as well ensure that all possess the knowledge, skills and attitudes that are in accordance with the requirements of society and labor market. Because of this, education must be accessible to everyone who lives in this society, regardless of age, gender, religious determination, health, ethnicity and socio-financial situation. Also, education and training must have all the conditions for efficiency and effectiveness, in order to be able to offer all general and professional education. Education should be characterized by a certain dynamic and flexible structure, which would enable mobilization of pupils, students and teachers, which will operate with clear mechanisms that will enable adaptation and willingness to deal with the requests for changes of individuals and society in general. Also, education must overcome issues and eliminate factors that promote absence of education and flood of users of educational services. Particular attention should be paid to the differences that will be manifested in the areas of: quality of teaching, learning conditions, adequate infrastructure, possession with adequate staff and physical access into educational institutions. Society must create comprehensive opportunities for education also encourage and motivate them to use these opportunities to improve their position in society, to aim for self actualization, regardless of their social background and educational level. The individual should aim to be updated and actual in the workplace. If he will not be updated and actual, then the results at work will not be enjoyable

Lifelong education is a continuous process of implementation of real opportunities of learning and self learning, in order to unconventionally, indirectly and directly, to obtain knowledge and functional skills for successfully solving important problems at work, also social, family and personal problems. If you rely on the rapid changes occurring in society, and the explosion of new knowledge and aging of them for a short time, it is considered that lifelong education is a necessity of the time. Scientific, technical, technological changes impose lifelong education so that we can move forward and together with all developed countries towards global change.

\subsection{Forms of lifelong learning}

Lifelong Education includes all stages of human life and helps in overcoming the youth education and supplementary education for adults. It emphasizes the man who is educated and not the educational institutions, recognizing, in this way, that education can be accomplished in many different ways and not necessarily in school, under the guidance of teachers and giving exams.

Lifelong Education includes:

a. formal education

Formal education is realized in education and training institutions, which provide officially recognized certificates and qualifications and it is structured (in relation to the goals, objectives, duration and the means by which is realized). ${ }^{1}$

b. Non-formal education

Non-formal education is provided through the activities of organizations and civil society groups, such as youth organizations, trade unions, political parties, as well as through additional services organizations or formal systems, such as art classes, music and sports or private lessons preparing for exams, it is typically structured and ends with award certificates that are not formally recognized or even without issuing certificates. ${ }^{2}$

\footnotetext{
1 Prof. dr. Pajtim Bejtja, Të nxënët në shoqërinë e sotme, Tiranë, 2003, fq. 3.

2 Ibid.
} 
c. informal education

Informal education is follow up of the activities that take place during everyday life at work, at home or at leisure, usually unintentional (accidental), so it is unstructured and does not lead to any certification. ${ }^{3}$

\subsection{Factors that determine the individual to determine for lifelong education ${ }^{4}$}

In the century which we live in, the changes are enormous, so human must necessarily be lifelong educated otherwise would not be able to perform professional duties that arise. There are a number of factors that determine lifelong education, among others will include:

Motivation to be educated.- This is a very important factor, because the man to be educated continuously must have motive and incentive to learn.

Awareness of the need to be educated.- man must be aware of what he knows, what he learns and what you has to learn in the future;

A clear picture of what should be learned.- man must clearly know what he has to learn what he needs to learn;

Practicality of knowledge - in order the knowledge gained to stay longer in our memory and influence our work they must be exercised. Only with the practicality of knowledge, they can be functional and serve us in our work;

Filling, expansion and progressive development of Knowledge- we constantly have to expand and also update new knowledge, in order to go with technical and other scientific -technological developments;

Updating need- Adding knowledge, doubling them for a short time helps the man to be continually educated, because it also imposed for a job and a better life. This rapid change of information, and the desire to be present, promotes aspiration for lifelong education

\subsection{Audiovisual technique and the education}

The postwar generation of first world war (1914-1918) and especially that of the 1930s witnessed the birth and development of audiovisual civilization. The postwar generation of II world war grew in an environment in which audiovisual techniques was already fully installed. Children and adolescents of 1968s are fully living with picture and sound civilization. While children of after 1980s, already live and will live more and more in the world of computing. This means that, for some of them the audiovisual technique was rather new phenomenon, which failed to accept and use, for others, the environment provided all the conditions for an accelerated learning as this technique began to be a part of their psychological and personality forming development. For youngsters, the presence of "audiovisuals" is an evident fact and a necessity, such that they have the impression that you can not live witout ear headphones. First implications that can be drawn from such a simple conclusion is that pedagogical problems arising out of the audiovisual intervention in the educational process of a few decades ago are no longer the same as those faced today. For this reason there can be distinguished the main following stages.Problems of 1940-1950s were associated with the use of instruments, purely psychological aspects of perception on the screen. In its beginings audiovisual technique was considered as completing the educational process introduced by the teacher, slowly, it was integrated into the teaching process, but always assecond element ${ }^{5}$ Audiovisual technique does not remain in the helping role of pedagogical action. It has a central role, being considered today as one of the major elements of the pedagogic action across the spectrum of its constituent ingredients: information, learning and expression. Until a century before, the knowledge sources of an adult were; the family, the physical environment, economy, schools, newspaper reading books, personal and professional experience. Radio and TV are sources of new knowledge, qualitatively different from the previous ones in terms of quantity as well. Just in front of us now is developed actualization and "internationalization" of knowledge.Information, cultural programms, propaganda, publicity etc.

\subsection{Audiovisual technique and new processes}

Audiovisual technique, that one of illustrated publications, cartoons, cinema or television to reach the fixed images on the screen, has caused birth of a new form of perception; two dimensions perception of a reality which is three dimensional itself, a perception that necessarily introduces a form of passivity without reference to J. Piaget works on

\footnotetext{
3 Ibid.

${ }^{4}$ Ligjërata të nivelit master, Prof. dr Demë Hoti.

5 Gastron Mailaret, Pedagogjia e Përgjithshme, Koha, Prishtinë, 1997, fq.430
} 
the child's conception of space. Increasingly the question of how elementary student integrates a highly complex landscape plan that gives adults the notion of depth or distance. The teacher is constantly in the flux of possible errors of interpretation of a document and is bound to make the necessary corrections without delay. In fact, what the film shows us is a series of successive images related to the same subject, figures which we are obliged to follow one after another in the order given, to try to integrate the perceived object, place, event or landscapes in their entirety. Cinema, radio and television, are excellent tools for information transmission, while the inactivity of the auditor or spectator is not indicative of a real communication. It is this reason why the teacher must have a minimum of knowledge about makin a film laws, on the type of film language used to help young viewers develop their critical spirit. Audovisual technique is not neutral in this respect 6 .

\subsection{CD player}

Cd player is a small instrument, which has not taken its rightful place in the midst of an educational situation. With its ease of use, it is audible witness of what happens in a classroom or what means a certain subject. Its practical use for repeating effect turns in a superb instrument of learning. Thanks to cd player the learning process has been a real revolution. Cd player plays magic mirror role in all educational situations that require verbal expression of subjects. ${ }^{7}$

\subsection{Television - short history}

In 1947, the US begin the first steps in television engagement in educational work, for which were made plans for first television educational programs. Systematic use of television in education starts around 1948 (Japan, USA, England), and educational programs begin to gain more space in programs and television companies. Television is an invention of the 20th century which conquered the world with great speed. Information was not obtained through the written rows anymore, but directly from the filming reality. People could see from their homes what was happening in the world. Television, in fact, changed people informing so quickly and revolutionary. It turned the world into what we call today global village. Prishtina's Television began work with the program in 1974. Television was discovered by John Logie Bard (british) and Vladimir Zworykin (Russian) in America. On October 2, 1925, in his laboratory Bardi has successfully transmitted the first television appearance.

\subsection{Television in schools}

Television in school creates conditions that general and vocational education to be acquired mainly through television. All those who wish to finish a certain type of school, get a qualification or further refine their profession can accomplish this with the help of television in school. "via television various curriculum are broadcasted and students watch, listen, take notes and try to remember." 8 the teacher gives adequate explanation, makes additions and gives certain tasks and thus students imbibe certain school program and benefit proper qualification. Students send questions to television, fill in answers and tests and undergo other modes of exams, while teachers, taking into account pedagogical requirements, organize and develop their teaching work.

\subsection{CD and DVD- television tools}

CD and DVDs are modern teaching tools that can be used successfully in the learning process. As Cd as well as DVDs have many options, ranging from their capacity, up to their potential for large scale exploitation for educational needs. CD and DVD also are practical, as their storage and their use. In these learning tools can be found films, documentaries, but recently has become common practice in $\mathrm{Cd}$ to be a whole book, from different areas. A CD or DVD can hold hundreds of thousands of information.

\subsection{TV contents and their relevance to lifelong education}

Through television content, individuals have the opportunity to see various events of great importance, which would

6 Gastron Mailaret, Pedagogjia e Përgjithshme, Koha, Prishtinë, 1997, fq.432

7 Mirko Bogičević, Tehnologija savremene nastave, Beogra, 1974, fq.177

8 Petar Mandiq, vep e cit. fq. 258. 
hardly be followed closely, or due to economic failure. Television has tremendous opportunity to offer your students an event when it is actually happening or through film, drawings and other material and provide different parts of the world, reconstruct events, provide data, show processes (chemical, biological, etc.), produce rare objects, concretize etc. Thanks to television broad popular masses can follow all political, cultural, scientific and sports events and thus became possible the expansion, deepening and updating of educational content, the modernization of methods and forms of teaching and learning. ${ }^{9}$. Television is a very powerful tool for informing the public. Broadcasting of television programs and experience in systematic educational television programs for schools has shown that television throughout the education system is a very important tool for the rationalization and modernization of the education system ${ }^{10}$

\section{Lifelong Education for you Means}

\section{Graph nr. 1}

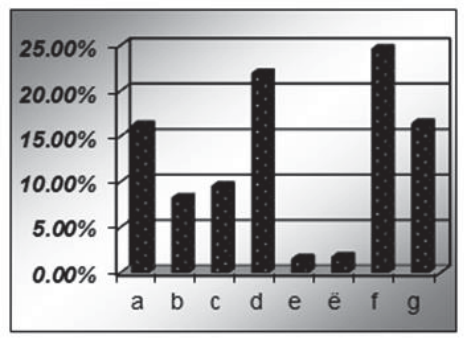

Table nr. 1

\begin{tabular}{|c|l|c|c|}
\hline Options & Level & $\mathrm{Nr}$ & Percentage \\
\hline a & Saving Time & 292 & $16.2 \%$ \\
\hline b & Saving Money & 148 & $8.2 \%$ \\
\hline c & Labor Preservation & 171 & $9.5 \%$ \\
\hline d & Spiritual Tranquility Preservation & 394 & $21.9 \%$ \\
\hline e & Personal Security & 28 & $1.5 \%$ \\
\hline ë & Anxiety and Stress Preservation & 30 & $1.7 \%$ \\
\hline f & Intellectual Condition Storage & 442 & $24.6 \%$ \\
\hline g & Social Balance Preservation & 295 & $16.4 \%$ \\
\hline & Total & 1800 & $100 \%$ \\
\hline
\end{tabular}

Legend: Time; b. Money, c. labor; d. Spiritual tranquility; e. personal security. ë. anxiety and stress; f. intellectual condition; g. society balance.

As to the question of what it means lifelong education for participants in the research, this result has been produced:

In first position is f option. Lifelong Education is the intellectual Condition storage. In second position is the option under d. Lifelong Education is the preservation of spiritual tranquility. In third position is the option $\mathrm{g}$. Lifelong education means preserve the balance in society. In fourth position is a option. Lifelong education is saving time, then come work option, money etc.

Lifelong Education is the intellectual Condition storage, preservation and conservation work the pace of change.

\section{Do you Watch Television?}

This question was submitted to elicit information from the respondents that do watch television. Depending on the answer given by the respondents, we continued or not with other questions.

${ }^{9}$ Dr. Petar Mandiq, Novacionet në mësim, ETMM, Prishtinë, 1985, fq. 244.

10 Rtv pedagogija, vep e cit. fq. 7. 


\section{Graph nr. 1.}

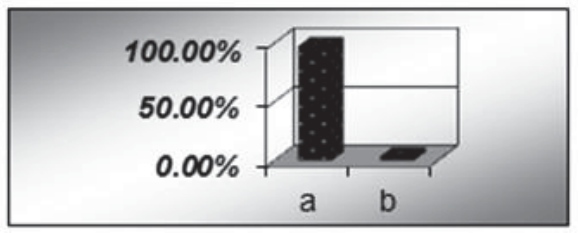

Table nr. 1.

\begin{tabular}{|c|c|c|c|}
\hline Options & Answers & Number & Percentage \\
\hline $\mathrm{a}$ & yes & 1749 & $97.2 \%$ \\
\hline $\mathrm{b}$ & no & 51 & $2.8 \%$ \\
\hline & Total & 1800 & $100 \%$ \\
\hline
\end{tabular}

Caption: On the question Do you watch television?, most of the participants in the research claimed that they watch television, while only are few of them said they do not watch television. Depending on the answer given to this question, we proceed or not with the two following questions. Subjects who said they do not watch television, we did not need to ask the question 2 and 3 . The answers show that $97.2 \%$ of Kosovo citizens find time to watch and actively monitor television programs. Out of these $57 \%$ were male and $40.2 \%$ were female. Differentiation based on age, about $35 \%$ are aged up to $18,21 \%$ aged $19-25$ years, $19 \%$ aged $26-45$ years, $16.2 \%$ aged $46-60$ years old, $6 \%$ aged over 60 years

About $96 \%$ of those living in villages and 98.4 of those living in cities watch television. Most of the citizens of Kosovo are interested to watch and watch TV regularly.

\section{Which Programs do you Watch More?}

Question has the purpose of obtaining information by respondents about programs they watch more..

\section{Graph.5}

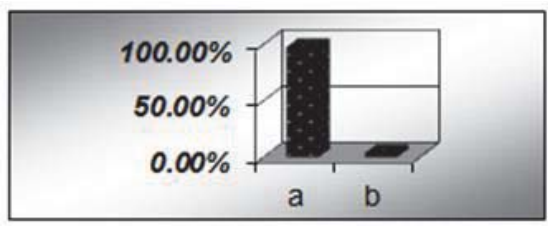

Table nr. 5.

\begin{tabular}{|c|c|c|c|}
\hline Options & Level & Number & Percentage \\
\hline A & Movies (Artistic, Serials etj) & 584 & $32.2 \%$ \\
\hline B & Music & 341 & $18.8 \%$ \\
\hline C & Educational Programs & 564 & $31.1 \%$ \\
\hline D & Other Porgrams & 324 & $17.9 \%$ \\
\hline & Total & 1813 & $100 \%$ \\
\hline
\end{tabular}

Legjenda:a. Filma (artistik, seriale etj) , Legend: a. movies b. Music c. educational programs d. other programs

In this question we got the following answers: Kosovo citizens mostly watch movies, so in the first place is option a, in second place is the option c.educational program, in third place is option b. music and at the bottom is option d. other programs. The outcome shows that educational programs occupy a very important place in the daily programs that citizen s of Kosova watch. However there is further need to provide more, and also educational programs to be followed more by the citizens. 


\section{Label some National or International Tv Channels that you Watch for your Educational Raise?}

\section{Graph nr. 6}

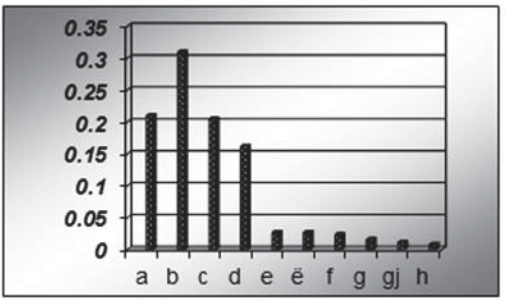

Table nr. 6

\begin{tabular}{|c|c|c|c|}
\hline Options & TV channel & $\mathrm{Nr}$ & Percentage \\
\hline $\mathrm{a}$ & Explorer & 780 & $21 \%$ \\
\hline $\mathrm{b}$ & RTK & 1140 & $31 \%$ \\
\hline $\mathrm{c}$ & KTV & 760 & $20.5 \%$ \\
\hline $\mathrm{d}$ & TV 21 & 600 & $16.2 \%$ \\
\hline $\mathrm{e}$ & Discover & 100 & $2.7 \%$ \\
\hline$\ddot{e}$ & Top Chanel & 100 & $2.7 \%$ \\
\hline$f$ & BBC & 90 & $2.4 \%$ \\
\hline$g$ & Besa & 60 & $1.6 \%$ \\
\hline gj & Tema & 40 & $1.1 \%$ \\
\hline h & Mitrovica & 30 & $0.8 \%$ \\
\hline
\end{tabular}

Legend: a. Eksplorer; b. RTK; c. KTV; d. TV 21; e. Discover; ë. Top channel; f. BBC; g. Besa; gj. Tema; h. Mitrovica;

Regarding the TV channels that can be watched in our country, we have a rating of about 10 TV channels followed by the citizens of Kosovo, but we will enumerate only a few who followed the highest percentage of citizens. In first position is Kosovo's public television RTK, in second place digital TV channel: Explorer, then comes the television channel KTV and after him comes TV 21. Six other TV channels are followed by a small number of citizens. Some of these TV channels can not be watched by many people because of the extent of their relay. While for some other channels (Explorer for instance), in some rural areas where there are no cable network installation and they cannot afford the digital access, it is impossible to watch these channels.

\section{How Much are you Satisfied with the Quality of Educational Programs that Broadcast Television Kosovo?}

The purpose of this question was to have opinions on how much information is provided for lifelong learning.

\section{Graph nr. 5}

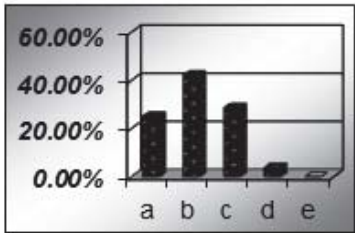

Table nr. 5

\begin{tabular}{|c|c|c|c|}
\hline Options & level & $\mathrm{Nr}$ & Percentage \\
\hline$a$ & A lot & 374 & $25.2 \%$ \\
\hline$b$ & Relatively & 626 & $42.2 \%$ \\
\hline C & Average & 427 & $28.7 \%$ \\
\hline$d$ & A little & 58 & $3.9 \%$ \\
\hline $\mathrm{e}$ & Not at all & 0 & $0 \%$ \\
\hline & total & 1485 & $100 \%$ \\
\hline
\end{tabular}

Legend a. A lot; b. relatively; c. average; d. a little; e. not at all 
According to most participants, whether they are satisfied with television channels that broadcast quality educational programs, they say that it helps for new information from the world of latest technical and technological developments, also there are information about books containing, educational programs for kids, etc. The skills to use the print and electronic resources, help you relatively a lot for lifelong education. In second place stand a group of participants who think that these are average qualitative educational content and there is still need for improvement. In third place is the option a).a lot there is a high quality of the educational contents in Kosovo's TVs. While the terms of the option d) has stated that few programs that broadcast quality programs with educational character, and to the last question did not have any correspondent who has provided an answer on this question. Quality education programs have great importance to the general public viewer on new information.

\section{Do you Use Other Electronic Resources and Media to your Lifelong Education?}

The purpose of this question was to obtain information whether participant use other resources for their lifelong education.

\section{Graph nr. 6}

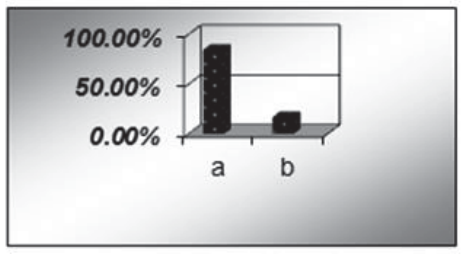

Table nr. 6

\begin{tabular}{|c|c|c|c|}
\hline Options & answers & $\mathrm{Nr}$ & Percentage \\
\hline $\mathrm{a}$ & yes & 1508 & $83.8 \%$ \\
\hline $\mathrm{b}$ & no & 292 & $16.2 \%$ \\
\hline \multirow{2}{*}{} & total & 1800 & $100 \%$ \\
\hline
\end{tabular}

Legend: a. Yes; b. No.

Most participants in the survey say they use other electronic resources and media for their lifelong education. A small number said they cannot exploit these resources.

The reason why the citizens of Kosovo do not use other resources for their educational establishment is that, as more resources are used more information is taken. If they use only the television they could not take much knowledge as well as a few television channels broadcast educational programs for adults

\section{Conclusions and Recommendations}

Based on theoretical analysis and practical problem, we can see that television is an important medium for educational establishment, however the actual television centers in Kosovo does not offer enough programs for adult education. Regarding this issue, we draw some conclusions:

Most of Kosovo's citizens watching television meaning they have access to television, most follow local channels on television, more viewers and highest broadcast quality has national television RTK, but the citizens of Kosovo use also other educational resources for their lifelong educational advancement. From the results obtained, we concluded that $53.7 \%$ of respondents are constantly educated in order to gain more knowledge, $14.3 \%$ of them want to have good income, $5.5 \%$ of them want to be advanced at work, equally wish to be updated in the workplace, $2.3 \%$ want higher position, $14.7 \%$ want to be role models for their children, while $4 \%$ of the respondents have other reasons for continuous education. 


\section{References}

Andoni, Mirela, Ejvis Shehi : " Gjendja e arsimimit të të rriturve dhe prirjet e tij në Shqipëri", ", "Revista pedagogjike", 2003, nr. 4, ISP, Tiranë.

Bejtja prof. dr. Pajtim ( 2003), Të nxënët në shoqërinë e sotme, Tiranë.

Bejtja prof. dr. Pajtim: "Të nxënët gajtë gjithë jetës- koncept udhëheqës për reformimin e arsimit dhe formimin profesional", "Revista pedagogjike", 2001, nr. 2, Tiranë.

Bogićević, Mirko (1969) Tehnologjia savremene nastave, Zavod za udžbenika, Beograd.

Deëey John Shkolla dhe Shoqëria Përkth Akil Bubesi), Tiranë, 2003.

Gjorgjeviq,Jovan,(1986),Mësimi Bashkëkohor,ETMM, Prishtinë.

Hatixhe dr. Ismaji, Teknologjia mësimore dhe të menduarit kritik, Prishtinë, 2012.

Kërneta Dr.Lubomir, Milena Potkonjak, dr. Nikolla Potkonjak - Pedagogjia

Koliqi Hajrullah Sistemi i arsimit në Kosovë (2004), "Libri shkollor", Prishtinë

Kraja, pro.dr. Musa (2002), Pedagogjia, "Libri Universitar', Tiranë.

Ligji për arsimin fillor dhe të mesëm, Prishtinë, 2002.

Ligji për arsimin dhe aftësimin e të rriturv (nr. 02/L-24), Prishtinë, 2005.

Ligji për arsimin dhe aftësimin professional (nr. 02/L-42), Prishtinë, 2006.

Mandiq Dr.Petar (1985), ETMM, Novacionet në mësim, Prishtinë.

Murati, Prof.dr.Xheladin (2004), Pedagogjia e përgjithshme, "Logos-A", Shkup.

Rtv pedagogija (1970), "Mladost", Zagreb.

Shahini, prof. as. Dr. Ladi "Globalizimi dhe arsimi", Revista ped",2002,nr.1, ISP, Tiranë.

Shifra dhe fakte për arsimin e Kosovës (2000), KEC, Prishtinë.

Shimlesha, Dr. Pero ( red. ), (1988), Pedagogjia, ETMM, Prishtinë.

Zylfiu Dr.sc.Nijazi (2001, 2005), Didaktika, UP, Prishtinë. 